
3 Research Square
Preprints are preliminary reports that have not undergone peer review.
They should not be considered conclusive, used to inform clinical practice, or referenced by the media as validated information.

\title{
Seismic Behavior of LRB and FPS Type Isolators Considering Torsional Effects
}

\author{
Esra Ozer \\ Pamukkale Üniversitesi: Pamukkale Universitesi \\ Mehmet Inel ( $\nabla$ minel@pau.edu.tr) \\ Pamukkale Universitesi https://orcid.org/0000-0002-8323-259X \\ Bayram Tanik Cayci \\ Pamukkale Üniversitesi: Pamukkale Universitesi
}

\section{Research Article}

Keywords: Base isolation, torsion behavior, lead rubber isolator, friction pendulum isolator, time history analysis

Posted Date: March 16th, 2021

DOI: https://doi.org/10.21203/rs.3.rs-307947/v1

License: (a) This work is licensed under a Creative Commons Attribution 4.0 International License. Read Full License

Version of Record: A version of this preprint was published at Structures on March 1st, 2022. See the published version at https://doi.org/10.1016/j.istruc.2022.01.011. 


\section{Abstract}

This study aims to investigate seismic behavior of LRB and FPS type base isolated models considering torsional irregularity due to distance between stiffness center of isolators and mass center of superstructure for low- and mid-rise reinforced concrete (RC) frame buildings with no shear walls. Nonlinear behavior of structural members was also considered to be able to observe probable yielding of structural members in superstructure due to the torsional irregularity. 528 different nonlinear time history analyses of 3-dimensional 3, 5, 7 and 9-story models subjected to 11 pairs of earthquake records were performed. The results indicate that FPS type isolators tend higher displacement demands while LRB type isolators are more sensitive to torsional effects. Torsional irregularity coefficient values of LRB models with $20 \%$ eccentricity are $47 \%$ higher than symmetrical models in terms of averages. Since significant part of the demands is absorbed by the isolator system, the remaining seismic demands for the superstructure is relatively low. Besides, the outcomes underline the careful selection of number of ground motion records in dynamic analysis as mentioned in the literature. While some studies in the literature indicate that torsional effects due to $10 \%$ or $20 \%$ eccentricity have significant role on building response, they used very limited building models subjected to a few earthquake records. The use of four different RC frame building model with LRB and FPS type isolators subjected to 11 pairs of ground motion records do not strongly support the abovementioned studies in literature. Therefore, more research is needed in this field.

\section{Introduction}

The loss of life and property caused by many large-scale past earthquakes has increased the importance of improving the seismic performance of facilities that contain valuable equipment and must continue to be used immediately after the earthquake such as hospitals, police and radio stations and telecommunication centers, etc. Base isolation technology is nowadays used as an option in seismic zones to improve seismic performance of structures subjected to earthquakes. The control of structural movements for such buildings is carried out with a specially designed interface at the level of isolators.

The main function of seismic isolators is to reduce the transmission of shear forces to the superstructure by extending the vibration period of the whole system, while providing enough rigidity at service load levels for wind and small earthquakes (Ceccoli et al. 1999; Erduran et al. 2011). Large displacement problems of isolation system can be eliminated by applying significant damping (Şengel et al. 2009). The desirable features of isolators are their low lateral stiffness with good energy dissipation and re-centering ability and vertical stability under the building weight and large displacements. The forcedisplacement behavior of typical isolator is nonlinear, hysteretic and can be idealized by either a rigid-linear, bilinear or tri-linear model (FEMA P-751 2012; FEMA P-1051 2016; McVitty and Constantinou 2015). The most common seismic isolator types in practice are lead-core rubber elastomeric bearing (LRB) and curved surface friction pendulum slider isolators (FPS) (Heaton et al. 1995).

LRB type isolators consist of steel plates between multiple rubber layers and lead core in the center (Ryan et al. 2005). The amount of damped seismic energy increases via lead core at LRB type isolators. Curved surface friction pendulum type isolators (FPS) perform the pendulum-like motion of an articulated slider on a concave friction surface. These isolators become active when the earthquake demands exceed the friction force on the isolator surface. With the movement of such isolators, a lateral force occurs in the system with friction and with the rise of the superstructure on the spherical surface. While this force is directly proportional to the weight carried by the isolator, it is inversely proportional to the radius of the concave surface.

Conventional FPS is essentially rigid under pressure and has no tensile load capacity while LRB has relatively less compressive stiffness and can withstand a limited amount of tensile load (Naeim and Kelly 1999). The huge disadvantage of the LRB type isolator is that the damage to the central lead core cannot be determined after a strong ground motion. Moreover, there is no self-re-centering feature as in the FPS type isolator. Previous research on the building response as a function of the isolator type revealed that elastomeric isolators (lead core rubber bearing (LRB)) take larger base displacements but transmit lower accelerations to the superstructure compared to friction pendulum isolator (FPS) (Jangid and Kelly 2001; Matsagar and Jangid 2004; Ordonez et al. 2003; Vaez et al. 2012). FPS type isolators are more stable against unwanted differences in the frequency content and amplitude of the earthquake. The lateral force generated by FPS type isolators, proportional to the weight of the structure, provides to coincide the center of mass of the building with the center of rigidity of the isolator system. This feature, proved in shake table tests by Zayas et al., eliminates the torsional effects that may occur (Mokha et al. 1991; Zayas and Mahin 1987).

The most important advantage of the LRB type isolator compared to the FPS type isolator is that it is generally more cost-effective and easier to install on site. In addition, lead core provides significant damping to the system at small level amplitude earthquakes. Previous research has generally focused on investigating a single type of base isolation system (Almazán and De la Llera 2002; Kelly 2003; Sharbatdar et al. 2011) instead of comparing different isolator systems in the same study (such as Hoseini Vaez et al. 2012).

Although there are many studies in the literature on the development and use of isolator systems, there are relatively few studies on the effect of isolator system on the torsional irregularity of buildings (Ismail 2015). When column layout is not symmetrical in plan or stiffness capacity of base isolators varies, torsional effects in the structure may inevitably occur. While some studies in the literature indicate that torsional effects have significant role on building response (Nagarajaiah et al. 1993; Tena-Colunga and Zambrana-Rojas 2006) some other studies have concluded that these effects are negligible (Ismail 2015; Jangid and Datta 1994; Jangid and Datta 1994; Lee 1980; Nagarajaiah et al. 1993). When the literature is examined, limited number of ground motion records specific to a region were used to compare torsional irregularity on base isolation systems. The vast majority of previous studies related with base isolator systems considered simplified building models and ignored nonlinear behavior of structural members. The studies were conducted using either a single three-dimensional model or several two-dimensional models (Wu and Samali 2002).

The aim of this study is to evaluate behavioral differences of LRB and FPS base isolator systems considering torsional irregularity for low- and mid-rise reinforced concrete $(\mathrm{RC})$ frame buildings with no shear walls. For this purpose, three-dimensional 3, 5, 7 and 9-story building models were used to include majority of typical building stock. Building models with LRB and FPS type base isolators were compared for different static eccentricities due to difference in 
stiffness capacity of isolator members in order to reflect possible torsional irregularity. Although building system with base isolators generally remains in elastic limits, nonlinear behavior of structural members was also considered in order to be able to observe probable yielding of structural members in superstructure due to the torsional irregularity.

Dynamic analyses were performed by using 11 different bi-directional ground motion pairs by applying two horizontal components as $\mathrm{H}_{1}$ and $\mathrm{H}_{2}$ of ground motions records, simultaneously to achieve a detailed investigation for dynamic response of LRB and FPS base isolator systems with torsional irregularity.

\section{Modelling}

\subsection{Building models}

In the scope of the study, four different 3-dimensional (3D) Reinforced Concrete (RC) frame building models, were designed in accordance with the 2018 Turkish Building Earthquake Code (TEC 2018) without any structural irregularities as 3, 5, 7 and 9-story. These models are fully symmetrical for both orthogonal axes. Plan views of 3, 5, 7 and 9-story building models are given in Figure 1. Typical story heights are $3.2 \mathrm{~m}$ and the same for all floors. Concrete class and reinforcement class were selected as C30 and S420, respectively. Compressive strength of concrete and yield strength of steel values are assumed to be 30 and $420 \mathrm{MPa}$. The buildings used in the study were assumed to be located near Pamukkale University in Denizli, Turkey on soil type ZC. The structural models are typical beam-column RC frame buildings with no shear walls. The column and beam dimensions are provided in Table 1.

Beam and column elements are modeled as nonlinear frame elements with lumped plasticity by defining plastic hinges at both ends of beams and columns. SAP2000 provides both the use of default hinge and user-defined hinge property options (SAP2000 CSI). The user-defined hinge properties are used in this study (Inel and Ozmen 2006). In the critical sections of the beams and column members, moment-curvature analyzes were performed by considering the dimensions, longitudinal and transverse reinforcement contents and axial load levels using SEMAp program (SEMAp 2008). Rotation values required for the nonlinear analyses were defined in the SAP2000 program used in the modeling and analysis stages (SAP2000 CSI). Plastic hinges at column members were applied considering M2-M3 interaction since time history analyses performed as bi-directional. The effective section stiffness of column and beam members were defined 0.70El and 0.35El as defined in TEC-2018 (TEC 2018) respectively.

Table 1. The dimensions of the carrier system element

\begin{tabular}{|lllll|}
\hline Model & 3-Story & 5-Story & 7-Story & 9-Story \\
\hline Beam Elements & $300 \times 500$ & $300 \times 500$ & $300 \times 500$ & $300 \times 500$ \\
$(\mathrm{~mm} \times \mathrm{mm})$ & & & & \\
Column Elements & $350 \times 350$ & $400 \times 400$ & $400 \times 400$ & $400 \times 400$ \\
$(\mathrm{~mm} \times \mathrm{mm})$ & $400 \times 400$ & & $450 \times 450$ & $450 \times 450$ \\
& & & & $500 \times 500$ \\
\hline
\end{tabular}

\subsection{Base isolation modelling}

LRB and FPS type base isolator systems were considered in the scope of this study. The base isolated models were created by placing the isolators on the base level of the conventional 3, 5, 7 and 9-story buildings. Models with isolators are diversified with only LRB and only FPS models. An isolator is placed under each column. The center of stiffness of isolators coincides with the superstructure center of mass without any torsional irregularity and called as zeroeccentricity (e0) models. Additional models were obtained by changing the horizontal stiffness of the isolators to obtain $10 \%$ and $20 \%$ of plan dimension of building distance between stiffness center of isolators and mass center of superstructure. Since the $x$-direction of buildings is more vulnerable to torsional effects, the unidirectional eccentricity in $x$-direction $\left(e_{x}\right)$ was created at the isolator interface. The building models with $e_{b x} / L=0.1$ and 0.2 are called as e10 and 20 throughout the paper.

The desired damping amount is achieved more easily with the lead core placed at the center of the rubber type isolators (LRB) (Ryan et al. 2005). Typical view of LRB type base isolator model is shown in Figure 2a. The hysteretic behavior of the LRB isolator can be idealized as bi-linear, shown in Figure $2 \mathrm{~b}$. The parameters on the figure are characteristic strength $\left(\mathrm{F}_{\mathrm{Q}}\right)$, initial (elastic) rigidity $\left(\mathrm{k}_{1}\right)$, secondary (inelastic) rigidity $\left(k_{2}\right)$, effective stiffness $\left(k_{e}\right)$ corresponding to the horizontal force $(F)$ and isolator displacement $(D)$, effective yield strength $\left(F_{y}\right)$, and effective yield displacement $\left(D_{y}\right)$.

Figure 3 shows the FPS isolator and its hysteretic behavior. Unlike the hysteretic behavior of the LRB isolator, the parameters that make up the curve, $F_{Q}$ and $F_{y}$ are the same values and are equal to the product of the effective friction coefficient $(m)$ and the vertical force $(P)$ acting on the isolation unit. Besides, the values of $k_{2}$ and $k_{e}$ depend on the effective radius of curvature $(R)$ of the curved frictional isolation unit sliding surfaces.

Table 2. Design parameters of the used isolators 


\begin{tabular}{|c|c|c|c|c|c|}
\hline \multirow[t]{2}{*}{ Parameters } & Unit & 3-Story & 5-Story & 7-Story & 9-Story \\
\hline & & LRB & LRB & LRB & LRB \\
\hline $\mathrm{K}_{\mathrm{e}}$ & $\mathrm{kNm}$ & 143 & 305 & 294 & 252 \\
\hline $\mathrm{K}_{2}$ & $\mathrm{kNm}$ & 98 & 209 & 202 & 173 \\
\hline$F_{y}$ & $\mathrm{kN}$ & 14.7 & 31.3 & 34.2 & 39.7 \\
\hline $\mathrm{K}_{2} / \mathrm{K}_{1}$ & - & 0.69 & 0.54 & 0.5 & 0.46 \\
\hline $\mathrm{D}_{\max }$ & $\mathrm{m}$ & 0.35 & 0.40 & 0.40 & 0.45 \\
\hline \multirow[t]{2}{*}{ Parameters } & Unit & 3-Story & 5-Story & 7-Story & 9-Story \\
\hline & & FPS & FPS & FPS & FPS \\
\hline $\mathrm{K}_{\mathrm{e}}$ & $\mathrm{kNm}$ & 99 & 445 & 622 & 676 \\
\hline $\mathrm{K}_{2}$ & $\mathrm{kNm}$ & 76 & 99 & 85 & 124 \\
\hline $\mathrm{m}$ & - & 0.03 & 0.03 & 0.03 & 0.03 \\
\hline $\mathrm{R}$ & $\mathrm{m}$ & 2.24 & 2.24 & 3.05 & 4.24 \\
\hline $\mathrm{D}_{\max }$ & $\mathrm{m}$ & 0.35 & 0.40 & 0.40 & 0.45 \\
\hline
\end{tabular}

The design parameters of the isolator used in this study for the SAP2000 program (SAP2000 CSI) are summarized in Table 2. The design parameters of isolator systems were determined according to design displacement values $\left(D_{\max }\right)$ given in Table 2 . The models with $10 \%$ and $20 \%$ eccentricities were derived from symmetrical models by changing stiffness capacity of isolator members. The total stiffness capacity of asymmetric isolator systems was taken same as symmetrical models to better observe the torsional effects.

\subsection{Torsional irregularity}

The structure in the base isolation system is idealized as a rigid platform with masses collected in corresponding column positions as shown in Figure 4. The base deck, which is considered to have a rigid diaphragm behavior, is supported by massless isolators that cannot extend axially. The center of rigidity (Kayhan et al.) of the isolator system does not generally coincide with the base deck or the center of mass (CM) of the superstructure. This situation causes the torsional moment due to the earthquake force, with the force arm equal to the distance between $\mathrm{CR}$ and $\mathrm{CM}$. As a result, the lateral movement of the system is combined with the torsional motion. Torsional effect occurs in both transverse directions. This study considers the most critical case, $e_{x}$-eccentricity of the system in the $\mathrm{x}$-direction as mentioned above.

TEC-2018 (TEC 2018) and all other similar seismic codes (ATC-40 1996; FEMA-356 2000) states that the design and construction of structures with torsional irregularity in the plan should be avoided, which has a negative impact on the earthquake behavior of the building. The definition of torsional behavior in TEC2018 is illustrated in Figure 4. According to TEC-2018 (TEC 2018), if the coefficient of irregularity $h_{b i}$ is greater than 1.2, torsional irregularity exists in structure as defined in Eq. 1. and are the maximum and minimum relative story displacements at the story level $\mathrm{i}$. The average relative story displacement is calculated as given in Eq. 2. Although there are constraints on torsional irregularity for superstructures in TEC-2018 (TEC 2018), there are no restrictions in the design of base-isolated systems.

$$
\begin{aligned}
\eta_{b i} & =\frac{\left(\Delta_{i}\right)_{\max }}{\left(\Delta_{i}\right)_{\text {average }}}>1.2 \\
\left(\Delta_{i}\right)_{\text {average }} & =\frac{\left(\Delta_{i}\right)_{\max }-\left(\Delta_{i}\right)_{\min }}{2}
\end{aligned}
$$

\section{Ground Motion Records}

Within the scope of the study, a total of 11 ground motion record sets were selected from the PEER Ground Motion Database of the Pacific Earthquake Engineering Research Center (PEER). Both components of these records $\left(\mathrm{H}_{1}\right.$ and $\left.\mathrm{H}_{2}\right)$ were scaled according to the elastic acceleration spectrum for $5 \%$ elastic damping ratio defined in TEC-2018 (TEC 2018). Scaling process was conducted using spectral matching, which is the most recommended earthquake record selection method for seismic codes (Kayhan et al. 2011).

The advantage of using spectrum matching is that the dispersion among analyzes is reduced and it enables a realistic estimation of the average response using less ground motion records (Karakütük 2015; NEHRP 2011). The design parameters were determined according to the location of the building as defined in TEC 2018 (TEC 2018). The buildings used in the study were assumed to be located near Pamukkale University in Denizli, Turkey on soil type ZC. The spectral parameters used for this location are given in Table 3 for the design earthquake with $10 \%$ probability of exceedance in 50 years. In the table, the short-period design spectral acceleration coefficient and the design spectral acceleration coefficient for the 1.0 second period are expressed as $S_{D S}$ and $S_{D 1}$, 
respectively. The short-period map spectral acceleration coefficient and the map spectral acceleration coefficient for the 1.0 second period are expressed as $\mathrm{S}_{\mathrm{S}}$ and $\mathrm{S}_{1}$, respectively.

Table 3. Ground parameters of design earthquake level (DD-2) for building location (TERM 2018)

\begin{tabular}{|ll|}
\hline Parameters & Value \\
\hline $\mathrm{S}_{1}$ & 0.261 \\
\hline $\mathrm{S}_{\mathrm{S}}$ & 1.135 \\
$\mathrm{~S}_{\mathrm{D} 1}$ & 0.658 \\
\hline $\mathrm{S}_{\mathrm{DS}}$ & 1.135 \\
\hline
\end{tabular}

The rules for the selection and scaling of earthquake records considering TEC-2018 (TEC 2018) criteria are given below:

- 3D time history analysis requires at least 11 pairs of ground motion records, not exceeding three record pairs from the same earthquake event.

- The same scale factor is applied in both horizontal components of the records.

- The mean spectra obtained as square root of sum of squares for the scaled ground motion records shall not be less than 1.3 times the target design spectrum between $5 \mathrm{~T}_{\mathrm{M}}$ and $1.25 \mathrm{~T}_{\mathrm{M}}$ periods for the base isolated buildings, where $\mathrm{T}_{\mathrm{M}}$ refers to the effective vibration period of building with seismic isolator subjected to the highest possible displacement.

- The ordinates of the site-specific earthquake ground motion spectra are never smaller than $90 \%$ of the design spectrum (horizontal elastic spectrum) ordinates.

- The nonlinear analyses in the scope of this study should performed as bi-directional.

The obtained elastic acceleration spectra are given in Figure 5 for the $5 \%$ damping ratio for the selected records. In addition, the spectrum of TEC-2018 on the ZC soil type with a probability of exceeding $10 \%$ in 50 years and the average of the ground motion records were plotted on the same figure. Although the scatter of the selected records is high, the average values are very close to the TEC-2018 spectrum requirement (1.3 times design spectrum). The properties of the ground motion records used are given in Table 4.

Table 4. Ground motion record properties used in the study (PEER)

\begin{tabular}{|lllllllllll|}
\hline No & RSN & Earthquake & Year & Location & Mw & Componenet & PGA & Vs30 & Scale \\
& & & & & $\mathrm{H}_{1} \mathrm{H}_{2}$ & $(\mathrm{~g})$ & $(\mathrm{m} / \mathrm{s})$ & Factor \\
\hline 1 & 88 & San Fernando & 1971 & Santa Felita Dam & 6.6 & $000-090$ & 0.387 & 389.0 & 2.5 & 1.5 \\
\hline 2 & 164 & Imperial Valley-06 & 1979 & Cerro Prieto & 6.5 & $000-090$ & 0.252 & 471.5 & 1.5 \\
\hline 3 & 302 & Irpinia_Italy-02 & 1980 & Rionero In Vulture & 6.2 & $000-270$ & 0.399 & 574.9 & 4.0 \\
\hline 4 & 313 & Corinth_Greece & 1981 & Corinth & 6.6 & $000-090$ & 0.592 & 361.4 & 2.0 \\
\hline 5 & 548 & Chalfant Valley-02 & 1986 & Benton & 6.2 & $270-360$ & 0.733 & 370.9 & 3.5 \\
\hline 6 & 1614 & Duzce_Turkey & 1999 & Lamont 1061 & 7.1 & E-N & 0.525 & 481.0 & 4.0 \\
\hline 7 & 1633 & Manjil_Iran & 1990 & Abbar & 7.4 & $000-090$ & 0.617 & 724.0 & 1.2 \\
\hline 8 & 3750 & Cape Mendocino & 1992 & Loleta Fire Station & 7.0 & $270-360$ & 0.531 & 515.7 & 2.0 \\
\hline 9 & 3759 & Landers & 1992 & Whitewater T.Farm & 7.3 & $180-270$ & 0.494 & 425.0 & 4.0 \\
\hline 10 & 5815 & Iwate_Japan & 2008 & Yuzawa & 6.9 & EW-NS & 0.791 & 655.5 & 4.0 \\
\hline 11 & 6915 & Darfield_N.Zealand & 2010 & Heathcote V. PS & 7.0 & $000-090$ & 0.930 & 422.0 & 1.2 \\
\hline
\end{tabular}

\section{Results And Discussion}

This study investigates seismic behavior of base isolated structures considering torsional effects. LRB and FPS type base isolation systems were designed with $0 \%, 10 \%$ and $20 \%$ of plan dimension eccentricity between mass center of structure and stiffness center of base isolation system. The same target displacement value was used at design stage to compare the effect of torsional irregularity and base isolator types on seismic response, properly. Since the torsional effects of the system were reflected by placement of isolators, there was no need to create torsional irregularity in the superstructure. Therefore, the superstructure models do not contain any torsional irregularities and are fully symmetrical. The torsional irregularity occurring in the isolator system is much more critical since a significant part of the seismic demands will be damped by the isolator system before transmitting to the structure. In the scope of this study, 528 different nonlinear time history analyses of 24 different models were performed considering 11 pairs of spectrum compatible record set. 
The building model parameters are summarized in Table 5 as total seismic weight $(W)$, dominant vibration periods $\left(T_{x}, T_{y}\right.$ and $\left.T_{z}\right)$ and base shear force values $\left(V_{t x}\right.$ and $\left.V_{t y}\right)$. The period shifting is obvious for base-isolated system compared to fixed-base models. It is obvious that FPS type base isolated models tend to have lower vibration periods compared to the LRB type base isolated models. The reason for this outcome is that FPS type isolators modeled according to the same design displacement have generally higher effective stiffness values.

Table 5. Comparisons of model parameters.

\begin{tabular}{|llllll|}
\hline Model & & 3-story & 5-story & 7-story & 9-story \\
\hline Fixed & Tx (s) & 0.51 & 0.87 & 1.15 & 1.51 \\
\cline { 2 - 6 } & Ty (s) & 0.48 & 0.82 & 1.12 & 1.34 \\
& Tz (s) & 0.47 & 0.78 & 1.05 & 1.32 \\
\cline { 2 - 6 } & W (kN) & 4623.6 & 12753.8 & 19885.5 & 32623.2 \\
& $\mathrm{~V}_{\text {tx }}(\mathrm{kN})$ & 1549.8 & 3200 & 3472.6 & 4836.1 \\
\cline { 2 - 6 } e0 & $\mathrm{V}_{\text {ty }}(\mathrm{kN})$ & 1399.7 & 2996.7 & 3009.6 & 4565.2 \\
LRB & $\mathrm{Tx}(\mathrm{s})$ & 2.98 & 3.34 & 5.01 & 5.51 \\
\cline { 2 - 6 } & $\mathrm{Ty}(\mathrm{s})$ & 2.36 & 3.32 & 4.84 & 5.18 \\
\cline { 2 - 6 } e0 & $\mathrm{Tz}(\mathrm{s})$ & 1.95 & 3.15 & 4.24 & 4.87 \\
FPS & $\mathrm{Tx}(\mathrm{s})$ & 2.58 & 3.03 & 4.05 & 4.82 \\
\cline { 2 - 6 } & $\mathrm{Ty}(\mathrm{s})$ & 2.01 & 2.94 & 3.62 & 4.02 \\
\cline { 2 - 6 } & $\mathrm{Tz}(\mathrm{s})$ & 1.69 & 2.37 & 2.97 & 3.61 \\
\cline { 2 - 6 } & & & & & \\
\hline
\end{tabular}

Seismic response of building models with seismic isolators are compared using displacement and interstory displacement demands. The obtained displacement demands are normalized by building height while the interstory displacement demands are normalized by story height to obtain "roof drift ratio (RDR)" and "interstory drift ratio (IDR)" values.

\subsection{Evaluation of displacement demands}

The displacement values at the base isolation and roof level of the base isolated symmetrical building models subjected to the scaled ground motion records are listed in Table 6 for LRB and FPS type isolator models. The roof displacement demand ratios are plotted in Figure 6 . The figure illustrates that FPS type base isolated buildings tend to have higher roof drift demands compared to the LRB type base isolated buildings.

Table 6. The displacement values at the base isolation and roof level of the base isolated symmetrical buildings models 


\begin{tabular}{|c|c|c|c|c|c|c|c|c|c|c|c|c|c|c|c|c|}
\hline \multirow[t]{3}{*}{ RSN } & \multicolumn{8}{|c|}{ Roof Displacement (mm) } & \multicolumn{8}{|c|}{ Isolator Displacement (mm) } \\
\hline & \multicolumn{4}{|l|}{ LRB } & \multicolumn{4}{|l|}{ FPS } & \multicolumn{4}{|l|}{ LRB } & \multicolumn{4}{|l|}{ FPS } \\
\hline & $\begin{array}{l}\text { 3- } \\
\text { story }\end{array}$ & $\begin{array}{l}\text { 5- } \\
\text { story }\end{array}$ & $\begin{array}{l}\text { 7- } \\
\text { story }\end{array}$ & $\begin{array}{l}\text { 9- } \\
\text { story }\end{array}$ & $\begin{array}{l}\text { 3- } \\
\text { story }\end{array}$ & $\begin{array}{l}\text { 5- } \\
\text { story }\end{array}$ & $\begin{array}{l}\text { 7- } \\
\text { story }\end{array}$ & $\begin{array}{l}\text { 9- } \\
\text { story }\end{array}$ & $\begin{array}{l}\text { 3- } \\
\text { story }\end{array}$ & $\begin{array}{l}\text { 5- } \\
\text { story }\end{array}$ & $\begin{array}{l}\text { 7- } \\
\text { story }\end{array}$ & $\begin{array}{l}\text { 9- } \\
\text { story }\end{array}$ & $\begin{array}{l}\text { 3- } \\
\text { story }\end{array}$ & $\begin{array}{l}\text { 5- } \\
\text { story }\end{array}$ & $\begin{array}{l}\text { 7- } \\
\text { story }\end{array}$ & $\begin{array}{l}\text { 9- } \\
\text { story }\end{array}$ \\
\hline $88-0$ & 74.7 & 88.7 & 87.0 & 97.7 & 124.1 & 171.0 & 132.4 & 232.6 & 69.3 & 81.9 & 77.0 & 88.5 & 117.9 & 159.7 & 123.5 & 221.6 \\
\hline $88-90$ & 173.4 & 192.6 & 227.2 & 225.5 & 177.3 & 199.8 & 302.7 & 363.1 & 161.4 & 179.0 & 204.7 & 207.5 & 165.0 & 186.2 & 275.6 & 335.2 \\
\hline $164-0$ & 113.6 & 128.5 & 151.2 & 161.8 & 122.6 & 133.3 & 208.6 & 275.0 & 105.5 & 118.7 & 133.3 & 149.4 & 115.7 & 122.1 & 190.1 & 257.6 \\
\hline $164-90$ & 71.0 & 79.7 & 86.7 & 92.2 & 122.5 & 139.0 & 164.9 & 184.6 & 65.8 & 72.8 & 77.1 & 83.6 & 115.9 & 132.4 & 151.5 & 170.4 \\
\hline $302-0$ & 79.5 & 86.4 & 89.6 & 73.4 & 114.6 & 155.3 & 189.1 & 231.2 & 74.0 & 79.6 & 79.7 & 68.2 & 109.0 & 148.7 & 174.2 & 214.2 \\
\hline $302-90$ & 197.1 & 230.7 & 239.7 & 270.2 & 222.9 & 325.0 & 371.0 & 320.3 & 183.7 & 214.3 & 215.1 & 248.1 & 207.1 & 300.7 & 334.5 & 293.5 \\
\hline $313-0$ & 138.1 & 176.8 & 163.4 & 130.4 & 194.2 & 259.2 & 168.8 & 236.3 & 128.5 & 162.6 & 147.5 & 121.3 & 182.1 & 236.5 & 155.7 & 217.4 \\
\hline $313-90$ & 185.4 & 241.4 & 208.7 & 170.2 & 279.1 & 327.8 & 220.2 & 252.2 & 172.6 & 225.5 & 185.3 & 155.0 & 259.7 & 305.8 & 201.0 & 232.4 \\
\hline $548-0$ & 112.2 & 132.3 & 115.8 & 111.7 & 135.0 & 171.6 & 154.8 & 151.8 & 104.2 & 121.0 & 102.7 & 96.5 & 127.2 & 160.7 & 139.2 & 140.6 \\
\hline $548-90$ & 147.2 & 188.3 & 164.5 & 164.7 & 207.2 & 266.6 & 255.4 & 189.3 & 136.8 & 174.5 & 148.7 & 152.8 & 192.4 & 248.1 & 234.2 & 180.8 \\
\hline $1614-0$ & 137.5 & 131.8 & 172.0 & 227.9 & 162.5 & 145.2 & 202.9 & 325.1 & 127.6 & 121.4 & 153.8 & 209.1 & 152.5 & 136.9 & 186.1 & 301.0 \\
\hline $\begin{array}{l}1614- \\
90\end{array}$ & 178.9 & 179.1 & 212.7 & 291.4 & 144.7 & 188.4 & 299.7 & 294.8 & 166.5 & 166.0 & 192.3 & 271.9 & 134.3 & 176.8 & 270.8 & 272.5 \\
\hline $1633-0$ & 254.6 & 286.3 & 290.1 & 275.2 & 374.9 & 431.6 & 436.0 & 464.8 & 237.6 & 267.4 & 264.7 & 255.0 & 334.6 & 400.0 & 391.1 & 422.8 \\
\hline $\begin{array}{l}1633- \\
90\end{array}$ & 183.1 & 205.4 & 218.2 & 256.5 & 147.8 & 192.5 & 343.4 & 275.9 & 170.5 & 193.2 & 194.8 & 240.0 & 132.1 & 171.0 & 311.0 & 251.4 \\
\hline $3750-0$ & 221.0 & 221.5 & 263.3 & 325.1 & 211.5 & 237.3 & 282.4 & 287.4 & 207.0 & 208.6 & 242.2 & 305.2 & 197.0 & 224.4 & 257.6 & 269.3 \\
\hline $\begin{array}{l}3750- \\
90\end{array}$ & 358.5 & 406.3 & 436.5 & 479.4 & 376.0 & 432.5 & 446.7 & 500.5 & 335.1 & 382.1 & 400.0 & 450.0 & 335.2 & 400.0 & 400.0 & 450.0 \\
\hline $3759-0$ & 128.6 & 111.5 & 175.9 & 251.9 & 131.9 & 218.9 & 286.2 & 291.4 & 119.6 & 102.6 & 157.1 & 232.8 & 124.7 & 205.9 & 261.2 & 272.7 \\
\hline $\begin{array}{l}3759- \\
90\end{array}$ & 78.4 & 106.0 & 95.8 & 76.2 & 145.5 & 183.9 & 129.9 & 220.9 & 72.7 & 98.2 & 86.3 & 68.6 & 136.4 & 173.2 & 120.5 & 208.7 \\
\hline 5815-0 & 319.3 & 398.0 & 317.2 & 275.6 & 400.7 & 438.0 & 412.0 & 326.6 & 298.4 & 374.6 & 285.8 & 254.2 & 335.4 & 400.0 & 370.3 & 290.4 \\
\hline $\begin{array}{l}5815- \\
90\end{array}$ & 275.7 & 315.1 & 324.1 & 318.4 & 363.7 & 431.3 & 445.5 & 482.1 & 257.8 & 295.3 & 297.5 & 297.5 & 337.6 & 400.0 & 400.0 & 441.0 \\
\hline $6915-0$ & 99.8 & 111.3 & 129.2 & 164.5 & 115.7 & 177.9 & 217.8 & 207.7 & 92.6 & 103.7 & 115.3 & 151.8 & 108.9 & 167.6 & 200.9 & 186.0 \\
\hline $\begin{array}{l}6915- \\
90\end{array}$ & 205.5 & 249.5 & 269.9 & 269.4 & 166.0 & 240.3 & 336.5 & 290.3 & 191.5 & 233.7 & 246.5 & 249.8 & 155.4 & 224.7 & 308.2 & 264.4 \\
\hline Average & 169.7 & 194.0 & 201.8 & 214.1 & 201.8 & 248.5 & 273.0 & 291.1 & 158.1 & 180.8 & 182.2 & 198.0 & 185.3 & 231.0 & 248.1 & 267.9 \\
\hline
\end{tabular}

The roof level displacement demand ratios for asymmetric/symmetric models are also illustrated in Figure 7. It is observed that LRB type isolators are more sensitive to torsional effects. The average displacement demands of $10 \%$ and $20 \%$ asymmetric LRB type isolator models are $11 \%$ and $14 \%$ higher than symmetrical models in average. This difference is less than $5 \%$ for FPS type isolators. It should be noted that the obtained displacement demand values were obtained from total displacement of building and isolators with respect to ground. Therefore, it does not reflect the superstructure demands.

The obtained results indicate that significant scatter exists in displacement demands of individual ground motion records for all models. The effect of eccentricity in terms of mean values is limited. Similar to the previous studies, it is observed that frequency content of several ground motion records affects the dynamic response of the base isolated system (Güner 2012; Matsagar and Jangid 2010; Tena-Colunga and Zambrana-Rojas 2006). The scatter observed in Figure 7 illustrates that the frequency content effect is more critical especially for FPS type isolators.

The ratio of the maximum displacement of the isolator to the total displacement of the building is given in Figure 8 . Since the demand ratios showed a similar trend for all models, 3, 5, 7 and 9-story models were evaluated together. More than $90 \%$ of displacement demands were experienced by the isolator system regardless of the eccentricity ratio and isolator type. The eccentricity due to the distribution of isolator stiffness values have very limited effect on the isolator displacement demands. The superstructure displacement demands are significantly small. Therefore, the torsional effects on seismic behavior of structure are negligible. Since the eccentricity in the isolator members is much more critical, it can be predicted that the torsional irregularity on building plan will have a very limited effect. Besides, it is apparent that the base isolation system considerably decreases the superstructure displacement demands subjected to ground motion records. 
The average utilization rate of the isolator displacement capacity is given in Figure 9 . The used isolator capacities are calculated as $43.1 \%, 49.4 \%$ and $49.5 \%$ for $\mathrm{e}$, e 10 and e20 eccentricity of LRB type isolators while these values are $63.5 \%, 66.3 \%$ and $66.5 \%$ for FPS type isolators. The outcomes obviously show that the capacity utilization rate of FPS type isolators modeled according to the same design displacement value is significantly higher than the LRB type isolators. When the results are analyzed separately, it is seen that the capacity utilization rate for some ground motion records were approached to $100 \%$ for FPS type isolators. Therefore, the evaluation based on average values may be misleading. Moreover, the difference between minimum and maximum capacity utilization is more striking between $\mathrm{e} 0$ and e 10 models compared to e10 and e20 models.

\subsection{Evaluation of IDR demands-}

Interstory drift is recognized as an important damage indicator. Roof drift given in the previous section includes the displacement demand of base isolator. Therefore, the evaluation of interstory drift ratio (IDR) values is important parameter to determine the superstructure demand. Figure 10 compares maximum IDR values of all models. Damage limit levels according to TEC-2018 (TEC 2018) is also illustrated on the figure as "UU" and "LD" abbreviations corresponding to uninterrupted use and limited damage limits, respectively. The controlled damage level is not shown on the figure because no model has reached to this damage level.

When the IDR values are examined, they have similar trend with roof displacement demand ratios. The maximum IDR values are calculated for FPS type isolators. While none of LRB type isolator models exceeded to limited damage state, six cases of FPS type isolators are at the LD state for 3-story and 5-story asymmetric models.

In previous studies related with base isolated systems, it is concluded that torsional irregularity may have significant effects on seismic response. However, in these studies limited number of ground motion records were considered (Nagarajaiah et al. 1993; Nagarajaiah et al. 1993; Tena-Colunga et al. 1997). By the nature of dynamic analysis, high ratio of scatter in seismic demands is also observed in the scope of this study. In Figure 11, the IDR profiles of 7-story model is given for RSN-5815 record as an example. While the differences in average results are negligible for e0 and e10 eccentricity of LRB type isolators, e 10 eccentricity model estimated almost $100 \%$ higher IDR value compared to e 0 eccentricity model for RSN-5815 record. A similar trend is seen for the FPS type isolator with e20 eccentricity for the same ground motion record. Since the displacement demands highly depend on the nature of ground motion records, the use of several records can result in remarkably different demands compared to the demands of 11 pairs of ground motion records. The evaluation based on the average displacement demands using 11 pairs of ground motion records indicate that effect of asymmetry is limited on the base isolated systems. Therefore, the number of records is substantially important. The outcomes of this study underline the careful selection of number of ground motion records in dynamic analysis as mentioned in the previous study (Huang et al. 2008).

The average IDR values of all building models are compared for symmetric and asymmetric models in Figure 12. When all models regardless of story number are evaluated together, the base isolated e20 models demand $20 \%$ higher IDR values compared to the symmetrical models. Although there may be cases with significant differences due to asymmetry, almost all IDR values (except few cases) are within UU damage level. Therefore, all models considered in this study may be assumed at an acceptable level considering the average IDR values.

\subsection{Torsional coefficient values}

Torsional coefficients defined in TEC-2018 (TEC 2018) were calculated at the time of maximum IDR and plotted in Figure 13. The torsional irregularity coefficient limit of 1.2 is also shown on the figure. All coefficient values are smaller than the torsional irregularity limit for symmetric models of all buildings. As expected, the torsional irregularity coefficient values increase as the eccentricity ratio increases. Although the average coefficient values of the asymmetric models with $10 \%$ eccentricity is around the limit value, there are considerable number of cases that exceed the limit coefficient value. Moreover, the average coefficient values of the asymmetric models with $20 \%$ eccentricity are higher than the limit value except the 3 -story models. The outcomes clearly indicate that the eccentricity at the isolator causes torsional irregularity at the superstructure. Besides, the LRB type isolators are more vulnerable to torsional irregularity compared to the FPS type isolators.

The ratio of the average coefficient values of the asymmetric system to the symmetric system is given in Figure 14. Both scatter and the average values of torsional irregularity coefficient are quite high for the LRB type isolator models. Torsional irregularity coefficient values of LRB models with $20 \%$ eccentricity are $47 \%$ higher than symmetrical models in terms of averages. The FPS type isolator models are less affected from the asymmetry.

Since significant part of the demands is absorbed by the isolator system, the remaining seismic demands for the superstructure is relatively low. The variation of the torsional irregularity coefficient for RDR and IDR history is given as an example for RSN-1633 record in Figure 15 to better understand the effects of torsional irregularity on the superstructure behavior. Since similar trends were observed in all ground motion records, these graphs were not given separately for all sets. The figure illustrates the time dependent variation of the scattering of the torsional irregularity factor for the RDR and IDR values. As the eccentricity increases in base-isolation models, the frequency of torsional coefficients approaching maximum values increases significantly. Although the structural behavior is distorted by the torsional irregularity, its effect is limited due to significant damping of demands by the base isolator system. For this reason, it is more important to investigate the effects of torsional behavior on isolator behavior rather than superstructure behavior.

\section{Conclusion}

This study investigates the seismic behavior of LRB and FPS type base isolated models considering torsional irregularity for low-and mid-rise reinforced concrete (RC) frame buildings with no shear walls. Torsional irregularity is reflected with static eccentricities due to distance between stiffness center of isolators and mass center of superstructure. Although building system with base isolators generally behaves as elastic, nonlinear behavior of structural members was also considered to be able to observe probable yielding of structural members in superstructure due to the torsional irregularity. For this 
purpose, 528 different nonlinear time history analyses of 3-dimensional 3, 5, 7 and 9-story models were performed considering 11 spectrum compatible ground motion record pairs. The remarkable outcomes are summarized below:

- FPS type isolators tend higher displacement demands compared to LRB type isolators.

- It is apparent that the base isolation system considerably decreases the superstructure displacement demands subjected to ground motion records.

- As expected, over $90 \%$ of the seismic demands are absorbed by the isolator system for all models indicating that the buildings with base isolation experience significantly smaller interstory drift demands.

- The results obtained in this study show that LRB type isolators are more sensitive to torsional effects compared to the FPS type isolators. The average displacement demands of $10 \%$ and $20 \%$ asymmetric LRB type isolator models are $11 \%$ and $14 \%$ higher than the average displacement demands of symmetrical models. For FPS type isolators this difference is less than $5 \%$.

- The capacity utilization rate of FPS type isolators modeled according to the same design displacement value is significantly higher than the LRB type isolators. When the results are analyzed separately, it is seen that the capacity utilization rate for some ground motion records were approached to $100 \%$ for FPS type isolators. Therefore, the evaluation based on average values may be misleading. Moreover, the difference between minimum and maximum capacity utilization is more striking between e 0 and e10 models compared to e 10 and e20 models.

- The obtained results indicate that significant scatter exists in displacement demands of individual ground motion records for all models. Similar to the previous studies, it is observed that frequency content of several ground motion records affects the dynamic response of the base isolated system.

- The evaluation based on the average displacement demands using 11 pairs of ground motion records indicate that effect of asymmetry is limited on the base isolated systems. Therefore, the number of records is substantially important. The outcomes of this study underline the careful selection of number of ground motion records in dynamic analysis as mentioned in the literature.

- Torsional irregularity coefficient values of LRB models with $20 \%$ eccentricity are $47 \%$ higher than symmetrical models in terms of averages. The FPS type isolator models are less affected from the asymmetry.

- Since significant part of the demands is absorbed by the isolator system, the remaining seismic demands for the superstructure is relatively low. Therefore, the presence of irregularity in the superstructure may not affect the superstructure displacement demands.

- As mentioned in previous studies, it is more important to investigate the effects of torsional behavior on isolator behavior rather than superstructure behavior, especially for LRB type isolators.

- While some studies in the literature indicate that torsional effects due to $10 \%$ or $20 \%$ eccentricity have significant role on building response, they used very limited building models subjected to a few earthquake records. The use of four different RC frame building model with LRB and FPS type isolators subjected to 11 pairs of ground motion records do not strongly support the abovementioned studies in literature. Therefore, more research is needed in this field.

\section{Declarations}

\section{Funding}

No funding was received for conducting this study.

\section{Conflicts of interest/Competing interests}

The authors declare they have no financial interests.

\section{Availability of data and material}

Not applicable

\section{Code availability (software application or custom code)}

Not applicable

\section{Authors' contributions}

Authors' contribution is equal.

\section{Ethics approval}

There is no conflict in this study.

\section{Consent to participate}

Not applicable

\section{Consent for publication}

Not applicable 


\section{Acknowledgments}

Not applicable

\section{References}

1. Almazán JL, De la Llera JC (2002) Analytical model of structures with frictional pendulum isolators. Earthq Eng Struct Dyn. 31(2):305-332. https://doi.org/10.1002/eqe.110

2. American Society of Civil Engineers (ASCE) FEMA-356 (2000) Prestandard and Commentary for the Seismic Rehabilitation of Building Rehabilitation

3. ATC-40 (Applied Technology Council) (1996) Seismic Evaluation and Retrofit of Concrete Buildings. Applied Technology Council California. Vol 1 and Vol 2

4. Ceccoli C, Mazzotti C, Savoia M (1999) Non-linear seismic analysis of base-isolated RC frame structures. Earthq Eng Struct Dyn. 28(6):633-653. https://doi.org/10.1002/(SICl)1096-9845(199906)28:6<633::AID-EQE832>3.0.C0;2-3

5. Erduran E, Dao ND, Ryan KL (2011) Comparative response assessment of minimally compliant low-rise conventional and base-isolated steel frames. Earthq Eng Struct Dyn. 40(10):1123-1141. https://doi.org/10.1002/eqe.1078

6. FEMA-P-751 (2012) 2009 NEHRP Recommended Seismic Provisions:Design Examples In, Washington DC, USA

7. FEMA-P-1051 (2016) 2015 NEHRP Recommended Seismic Provisions:Design Examples. In, Washington DC, USA

8. Güner G (2012) Bir Hastane Yapısının Klasik Yöntemle Ve Sismik İzolatör Kullanılarak Tasarımının Dinamik Yönden Karşılaştırılmasının Yapılması. PhD Thesis. Institute of Science. ITU İstanbul Turkey (in Turkish)

9. Heaton TH, Hall JF, Wald DJ, Halling MW (1995) Response of high-rise and base-isolated buildings to a hypothetical Mw 7.0 blind thrust earthquake. Science 267(5195):206-211. https://doi.org/10.1126/science.267.5195.206

10. Hoseini Vaez S, Naderpour H, Kalantari S, Fakharian P (2012) Proposing the Optimized Combination of Different Isolation Bearings Subjected to NearFault Ground Motions. 15th World Conference on Earthquake Engineering (15WCEE). September (pp 24-28)

11. Huang Y-N, Whittaker AS, Luco N (2008) Performance assessment of conventional and base-isolated nuclear power plants for earthquake and blast loadings. MCEER-08-0019.University at Buffalo NY. https://doi.org/10.13140/rg.2.1.4371.6727

12. Inel M, Ozmen HB (2006) Effects of plastic hinge properties in nonlinear analysis of reinforced concrete buildings. Eng Struct. 28(11):1494-1502. https://doi.org/10.1016/j.engstruct.2006.01.017

13. Ismail M (2015) Elimination of torsion and pounding of isolated asymmetric structures under near-fault ground motions. Struct. Contr. Health Monit. 22(11):1295-1324. https://doi.org/10.1002/stc. 1746

14. Jangid R, Datta T (1994) Nonlinear response of torsionally coupled base isolated structure. J. Struct. Eng. 120(1):1-22. https://doi.org/10.1061/(ASCE)0733-9445(1994)120:1(1)

15. Jangid R, Datta T (1994) Seismic response of torsionally coupled structure with elasto-plastic base isolation. Eng. Struct. 16(4):256-262. https://doi.org/10.1016/0141-0296(94)90065-5

16. Jangid R, Kelly J (2001) Base isolation for near-fault motions. Earthq Eng Struct Dyn. 30(5):691-707. https://doi.org/10.1002/eqe.31

17. Karakütük Ö (2015) Effect of ground motion selection on seismic response of buildings. Master's thesis, METU, Ankara, Turkey (in Turkish)

18. Kayhan AH, Korkmaz KA, Irfanoglu A (2011) Selecting and scaling real ground motion records using harmony search algorithm. Soil Dyn. Earthq. Eng. 31(7):941-953. https://doi.org/10.1016/j.soildyn.2011.02.009

19. Kelly JM (2003) Tension buckling in multilayer elastomeric bearings. J. Eng. Mech. 129(12):1363-1368. https://doi.org/10.1061/(ASCE)07339399(2003)129:12(1363)

20. Lee DM (1980) Base isolation for torsion reduction in asymmetric structures under earthquake loading. Earthq Eng Struct Dyn. 8(4):349-359. https://doi.org/10.1002/ eqe.4290080405

21. Matsagar VA, Jangid R (2004) Influence of isolator characteristics on the response of base-isolated structures. Eng Struct. 26(12):1735-1749. https://doi.org/10.1016/j.engstruct.2004.06.011

22. Matsagar V, Jangid R (2010) Impact response of torsionally coupled base-isolated structures. J Vib Control. 16(11):1623-1649. https://doi.org/10.1177/1077546309103271

23. McVitty WJ, Constantinou MC (2015) Property modification factors for seismic isolators: Design Guidance for Buildings. MCEER report:15 - 0005

24. Mokha A, Constantinou M, Reinhorn A, Zayas VA (1991) Experimental study of friction-pendulum isolation system. J Struct Eng. 117(4):1201-1217. https://doi.org/10.1061/(ASCE)0733-9445(1991)117:4(1201)

25. Naeim F, Kelly JM (1999) Design of seismic isolated structures: from theory to practice. John Wiley \& Sons. https://doi.org/10.1002/9780470172742

26. Nagarajaiah S, Reinhorn AM, Constantinou MC (1993) Torsional coupling in sliding base-isolated structures. J Struct Eng. 119(1):130-149. https://doi.org/10.1061/(ASCE)0733-9445(1993)119:1(130)

27. Nagarajaiah S, Reinhorn AM, Constantinou MC (1993) Torsion in base-isolated structures with elastomeric isolation systems. J Struct Eng 119(10):2932-2951. https://doi.org/10.1061/(ASCE)0733-9445(1993)119:10(2932)

28. NEHRP Consultants Joint Venture (2011) Selecting and scaling earthquake ground motions for performing response-history analyses, NIST GCR 11-91715. In, Maryland, USA 
29. Ordonez D, Foti D, Bozzo L (2003) Comparative study of the inelastic response of base isolated buildings. Earthq Eng Struct Dyn. 32(1):151-164. https://doi.org/10.1002/eqe.224

30. Pacific Earthquake Engineering Research Center (PEER) (2019) Ground Motion Database. Available at: http://ngawest2.berkeley.edu/. Accessed 19.05.2019

31. Ryan KL, Kelly JM, Chopra AK (2005) Nonlinear model for lead-rubber bearings including axial-load effects. J Eng Mech. 131(12):1270-1278. https://doi.org/10.1061/(ASCE)0733-9399(2005)131:12(1270)

32. SAP 2000 CSI (2020) Integrated Software for Structural Analysis and Design. Computers and Structures Inc., Berkeley

33. SEMAp (2008) Sargı Etkisi Modelleme Analiz Programı Tubitak Proje No: 105M024 Ankara, Turkey (in Turkish)

34. Sharbatdar M, Vaez SH, Amiri GG, Naderpour H (2011) Seismic response of base-isolated structures with LRB and FPS under near fault ground motions. Procedia Eng. 14:3245-3251. https://doi.org/10.1016/j.proeng.2011.07.410

35. Şengel HS, Hakan E, Yavuz E (2009) Sismik İzolasyon Tekniği Ve Kullanılışına Illişkin Örnek Uygulama. Eskişehir Osmangazi Üniversitesi Mühendislik ve Mimarlık. Fakültesi Dergisi 22(2):165-178

36. Tena-Colunga A, Gómez-Soberón C, Mun oz-Loustaunau A (1997) Seismic isolation of buildings subjected to typical subduction earthquake motions for the Mexican Pacific Coast. Earthq. Spectra 13(3):505-532. https://doi.org/10.1193/1.1585960

37. Tena-Colunga A, Zambrana-Rojas C (2006) Dynamic torsional amplifications of base-isolated structures with an eccentric isolation system. Eng. Struct 28(1):72-83. https://doi.org/10.1016/j.engstruct.2005.07.003

38. Turkish Earthquake Code (TEC-2018) (2018) Republic of Turkey Prime Ministry Disaster and Emergency Management Authory Presidential of Earthquake Department. Ankara, Turkey (in Turkish)

39. Turkey Earthquake Risk Map (TERM) (2018) Türkiye Deprem Tehlike Haritası. Republic of Turkey Prime Ministry Disaster and Emergency Management Authory Presidential of Earthquake Department. Ankara, Turkey https://tdth.afad.gov.tr Accessed 08.09.2019

40. Vaez SH, Naderpour H, Kalantari S, Fakharian P (2012) Proposing the Optimized Combination of Different Isolation Bearings Subjected to Near-Fault Ground Motions.. In 15th World Conference on Earthquake Engineering (15WCEE), September (pp. 24-28)

41. Wu YM, Samali B (2002) Shake table testing of a base isolated model. Eng. Struct 24(9):1203-1215. https://doi.org/10.1016/S0141-0296(02)00054-8

42. Zayas VA, Mahin SA (1987) The FPS earthquake resisting system experimental report. Earthquake Engineering Research Center, USA

\section{Figures}
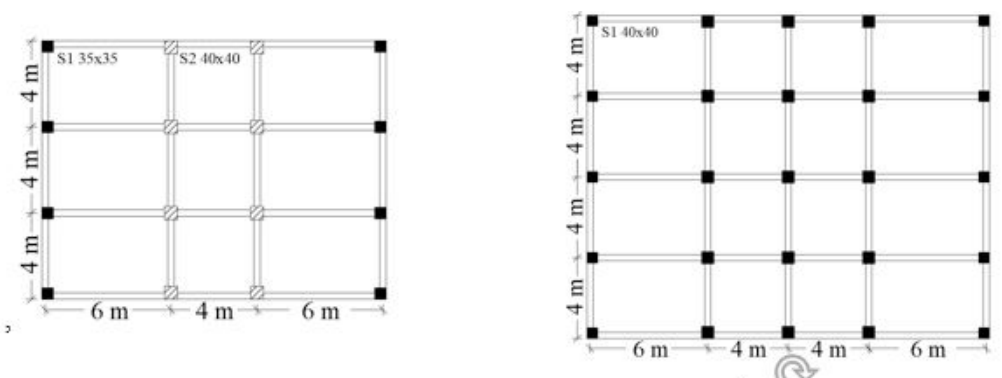

a. 3 -story

b. 5-story

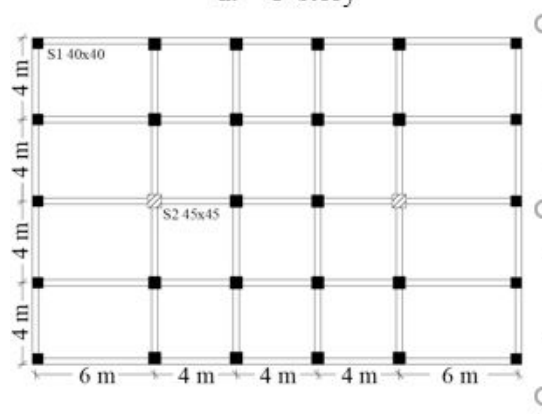

c. 7-story

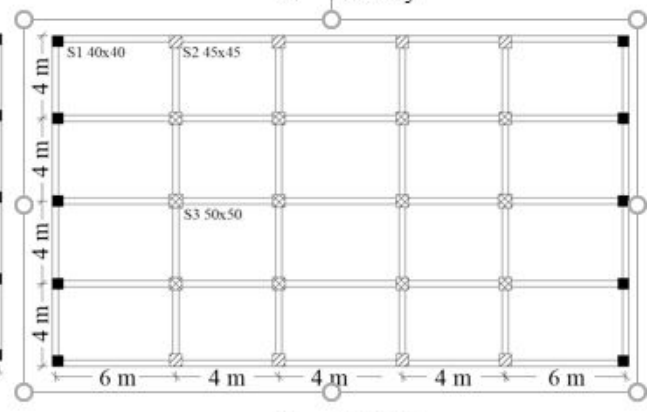

d. 9-story

Figure 1

Plan view of the considered buildings 


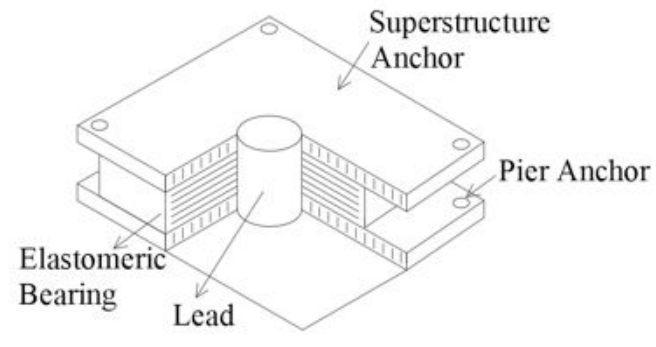

a. Laminated rubber bearing with lead core

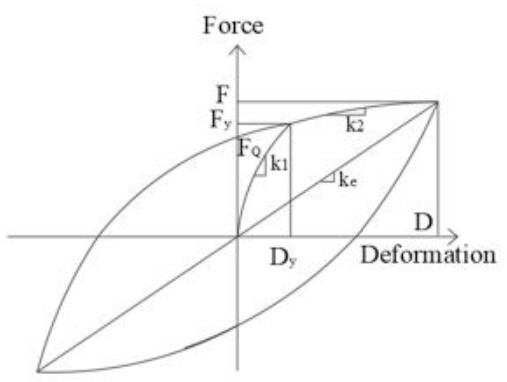

b. Idealized bilinear force-displacement relation of lead rubber isolator

Figure 2

Lead core laminated rubber bearing parts and its hysteresis model (TEC 2018)

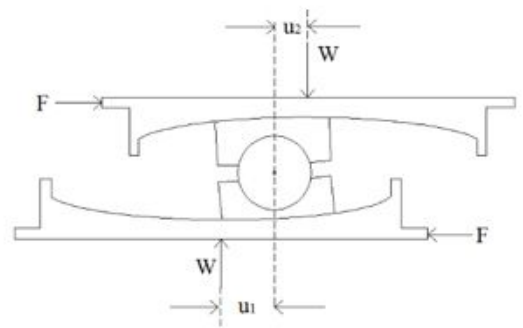

a. Friction pendulum system

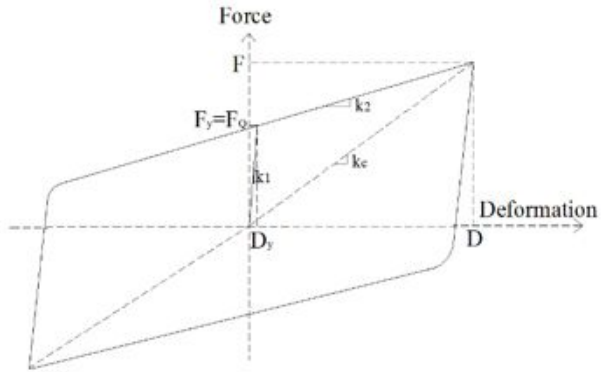

b. Rigid-linear force-displacement behavior of FPS isolator

Figure 3

Curved surface friction pendulum isolator parts and its hysteresis model (TEC 2018)
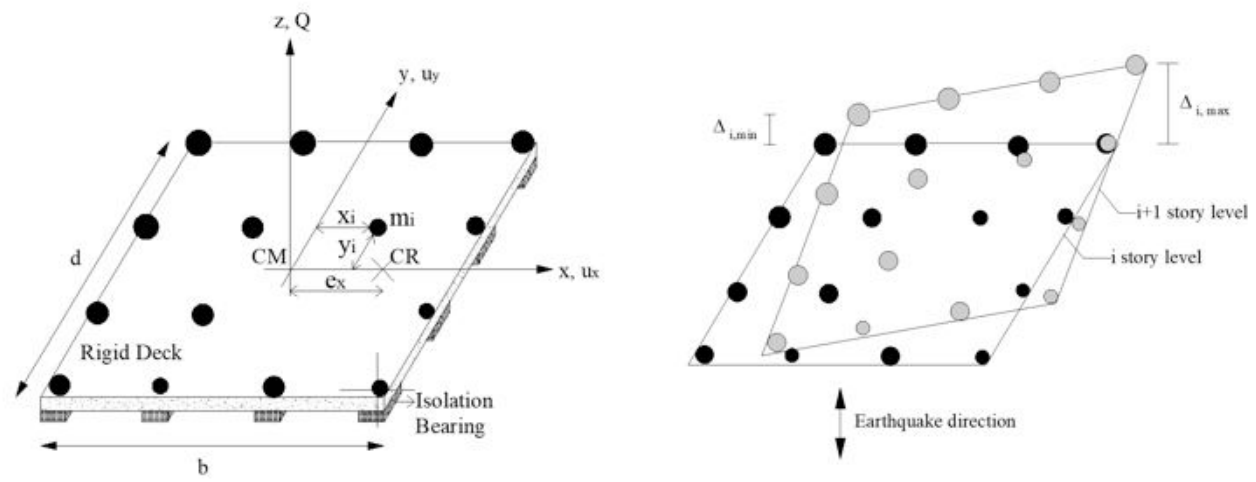

Figure 4

Torsional irregularity case (TEC 2018) 


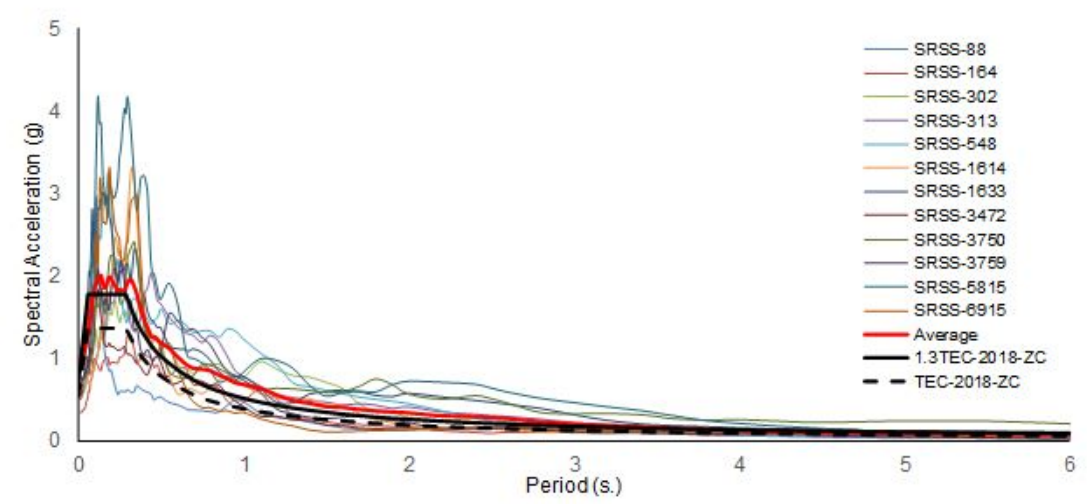

Figure 5

Elastic acceleration spectrum for $5 \%$ damping of ground motion records used in the study

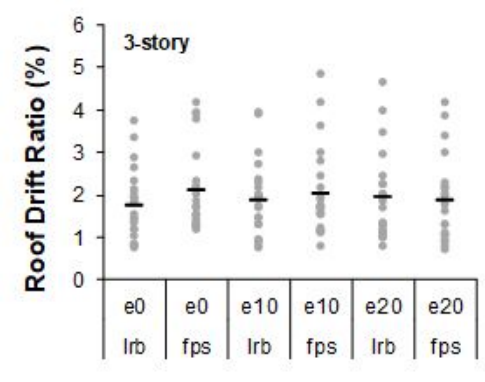

a.

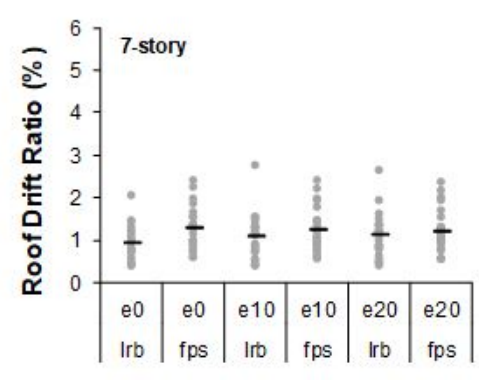

c.

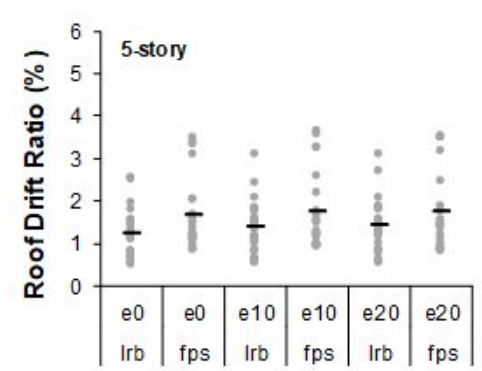

b.

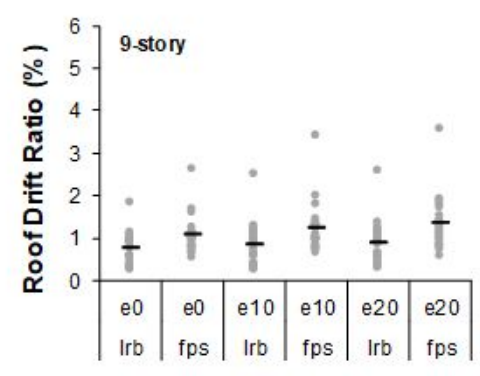

d.

\section{Figure 6}

Roof drift ratios of base isolated building models subjected to the scaled ground motion set

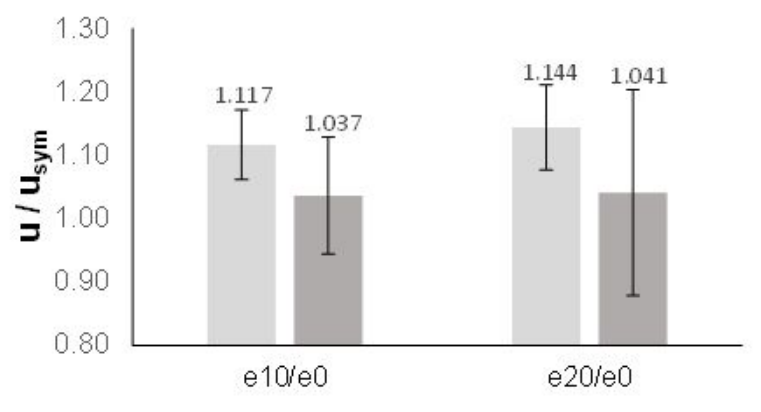

$m$ lrb $=\mathrm{fps}$

Figure 7

The ratio of average roof displacement of eccentric systems to the average roof displacement of symmetrical systems for all buildings 




Figure 8

Isolator displacement relative to total displacement

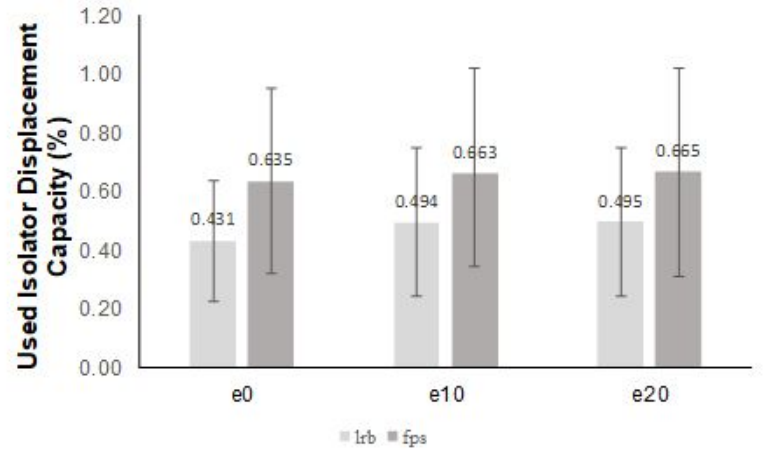

Figure 9

The average values of the isolator displacement capacity utilization

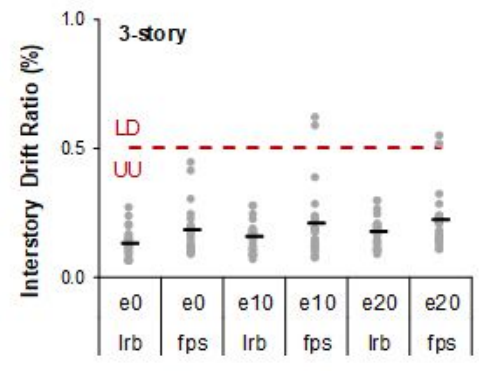

a.

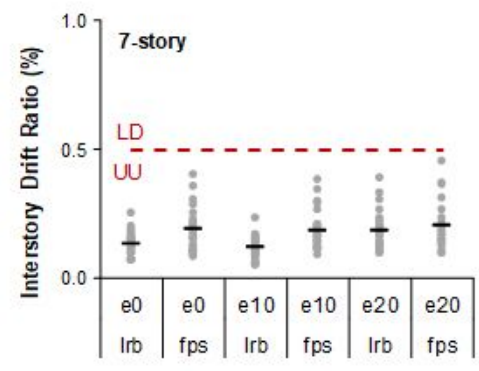

c.

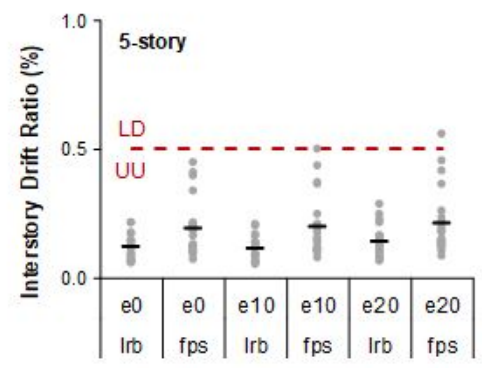

b.

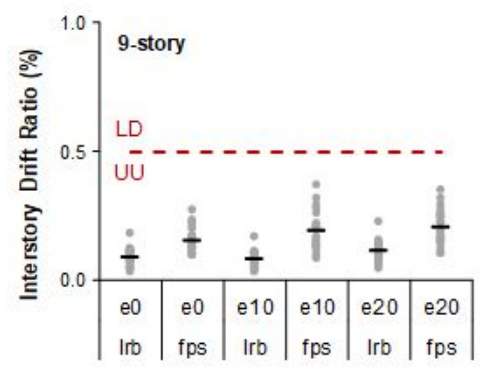

d.

Figure 10

Maximum interstory drift ratios for the building models 

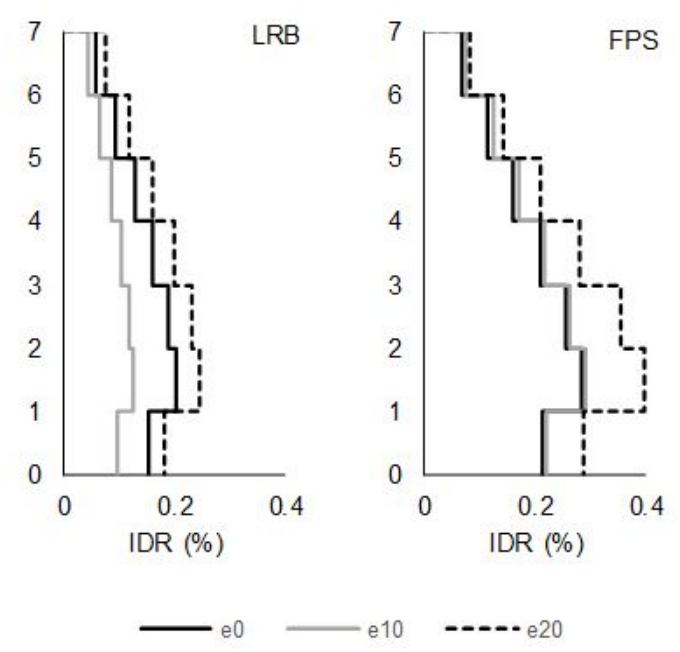

a.

b.

Figure 11

IDR profiles of 7-Story model for RSN-5815 record

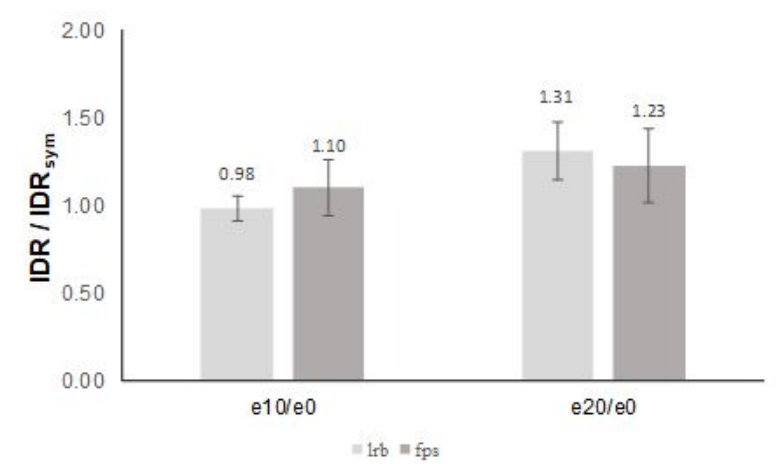

\section{Figure 12}

Displacement ratios compared to the system without eccentricity

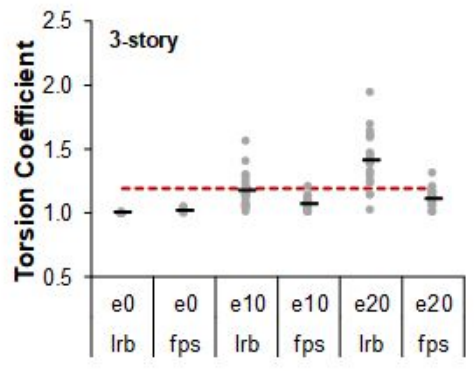

a.



c.

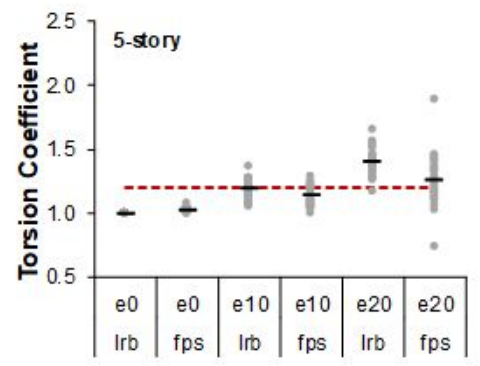

b.



d. 
Figure 13

Torsion coefficient ( $(\mathrm{b})$ for models

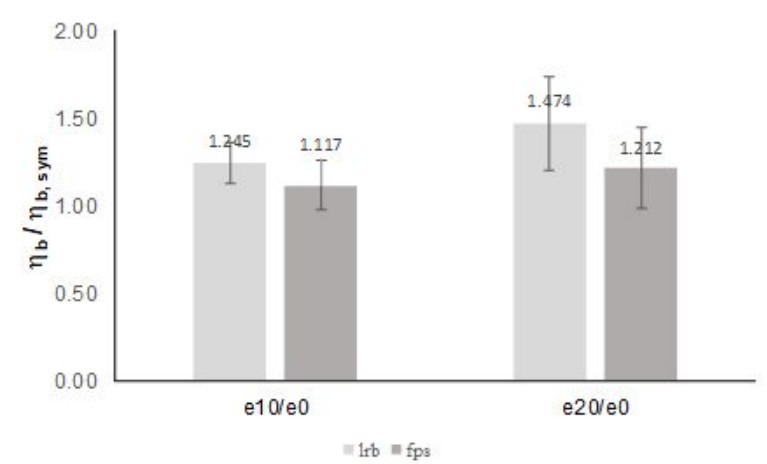

Figure 14

Torsion coefficient ( $(b)$ for models

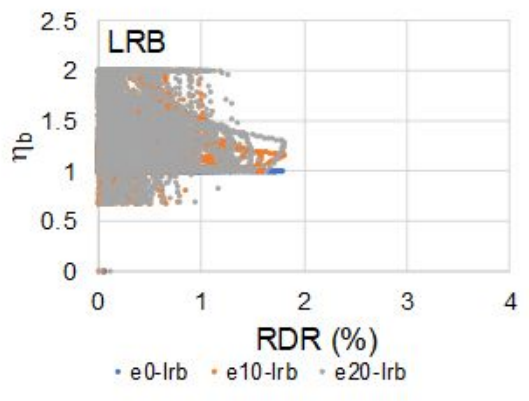

a.

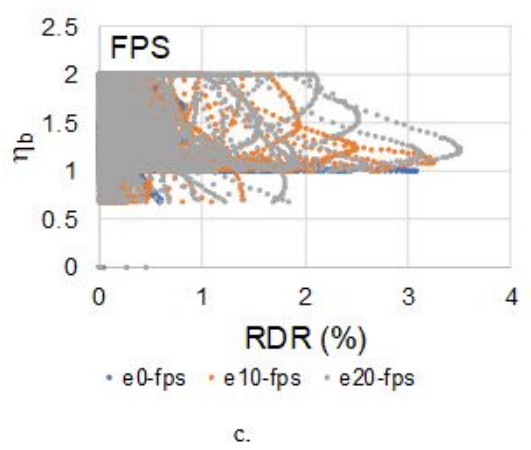

\section{Figure 15}

Torsion coefficient ( $\square$ b) scatter for RSN-1633

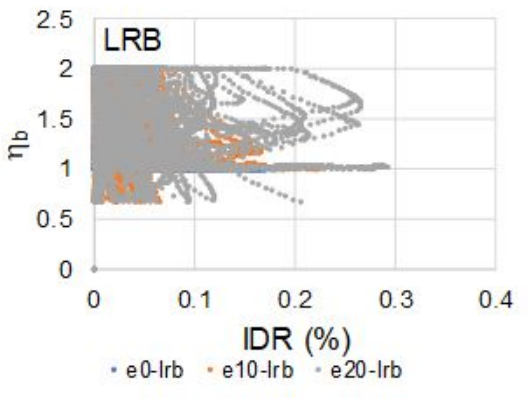

b.

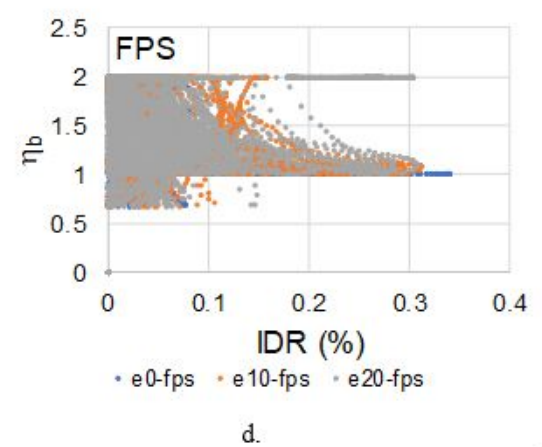

d. 